\title{
Evaluation of total phenolic content and antioxidant activity of different Rosmarinus officinalis L. ethanolic extracts
}

\author{
Giedrè Kasparavičiené $\dot{e}^{1 *}$ \\ Kristina Ramanauskien $\dot{e}^{2}$, \\ Arūnas Savickas', \\ Saulè Velžienè ${ }^{1}$, \\ Zenona Kalvẻniené $\dot{1}^{1}$ \\ Daiva Kazlauskiené $\dot{3}^{3}$ \\ Ona Ragažinskienè $\dot{ }^{4}$ \\ Kostas Ivanauskas ${ }^{5}$ \\ ${ }^{1}$ Department of Drug \\ Technology and \\ Social Pharmacy \\ ${ }^{2}$ Department of \\ Clinical Pharmacy \\ ${ }^{3}$ Department of Analytical \\ and Toxicological Chemistry \\ Lithuanian University \\ of Health Sciences, Lithuania \\ ${ }^{4}$ Vytautas Magnus \\ University, Lithuania \\ ${ }^{5}$ Department of Pathology, \\ Forensic Medicine and \\ Pharmacology, \\ Faculty of Medicine \\ Vilnius University, \\ Lithuania
}

Botanical extracts are one of the richest sources of antioxidants that counteract both free radicals and oxygen reactive species. The solvent and extraction conditions used in the extraction may influence the quantity, antioxidant composition and biological activity.

Ethanolic extracts of rosemary leaf were produced by maceration and percolation and different ethanol concentrations (30,40, $50,60,70,80,90$ and 96\%) were used for extraction. Influence of ethanol concentration and extraction method on the amount of total phenolic content and antioxidant activity and 1,1-diphenyl2-picrylhydrazyl (DPPH) radical inactivation were determined spectrophotometrically.

The most potent solvent concentration was $50 \%$ for the evaluation of total polyphenols $47.39 \pm 0.21 \mathrm{mg} / \mathrm{mL}$ RAE. All tested rosemary extracts showed high DPPH radical inactivation which ranged from $75.96 \pm 1.12 \%$ to $85.81 \pm 0.14 \%$, but no statistically significant difference $(\mathrm{P}>0.0624)$ was observed. The dry residue was also evaluated and it was higher in the liquid extracts than in tinctures. Stirring of rosemary leaves increased the total phenolics (from 42 till $53 \mathrm{mg} / \mathrm{ml} \mathrm{RAE}$ ) in the $50 \%$ ethanolic rosemary tincture.

Extraction by percolation showed higher amounts of dry residue and phenolics, but antioxidant activity was lower. Correlation between the total phenolic content and antioxidant activity was not observed. Active moistening is effective and can increase the amount of extractive substances from herbal materials.

Key words: Rosmarinus officinalis L., phenolics, antioxidant activity, ethanolic extracts

*Corresponding author. E-mail: giedre@kasparavicius.eu 


\section{INTRODUCTION}

Antioxidants are compounds capable of delaying, retarding or preventing oxidation. They can react with free radicals or can interrupt the chain reaction in the propagation of oxidation. The overproduction of free radicals and reactive oxygen species in humans can damage cellular lipids, proteins, or DNA. It contributes to development of wide range of human diseases: cancer, cardiovascular diseases, atherosclerosis, hypertension, ischemia, diabetes, neurodegenerative diseases, rheumatoid arthritis and aging (Valko et al., 2007). Botanical extracts are well recognized sources of antioxidants. It has been postulated that supplementation with phytochemicals such as polyphenols, including flavonoids, may offer some protection through their roles as free radical scavengers and antioxidant compounds, therefore reducing the negative effect of oxidative stress and free radicals (Seifried et al., 2007).

Rosmarinus officinalis L. (Lamiaceae) is a plant widely distributed in Europe, Asia and Africa and one of its growing areas is the Mediterranean basin. Rosemary is widely known for its numerous applications in the field of food but also for an increasing interest in its health promoting properties. There are three groups of compounds in the rosemary extracts: phenolic diterpenes, flavonoids and phenolic acids. The major antioxidant compounds are carnosic acid and carnosol, abietane-type diterpenes, rosmarinic acid, a hydroxycinnamic acid ester (Ozlem et al., 2007). According to the ESCOP (European Society Cooperative on Phytotherapy), ethanol and form of aqueous extracts rosemary leaves are used as coleretic, colagogue, epatoprotective, and antioxidants, but also as light diuretic, antiulcer, antitumor and antiviral products (Mulinacci et al., 2011).

Most of the reported results associated functional properties of rosemary with the composition of polyphenolic compounds. Therefore, the objective of this study was to evaluate the total phenolic content and antioxidant activity of different ethanolic extracts from rosemary leaves, and to investigate the relationship between phenolic content and antioxidant activity.

\section{MATERIALS AND METHODS}

\section{Plant material}

The object in this study was fluid ethanolic extracts from Rosmarinus officinalis L. The dried rosemary leaves were obtained from Bioset LTD (Plovdiv, Bulgaria).

\section{Extraction}

The fluid extracts of rosemary were produced by maceration and percolation methods (Kalveniene et al., 2002; Ramanauskiene et al., 2004). Maceration procedure was as folows: dried rosemary leaves placed in the closed vessel, solvent was added (1:5) $\rightarrow$ allowed to stand for 3 days by shaking occasionally $\rightarrow$ decantation of liquid part $\rightarrow$ ethanolic solutions were kept at $8{ }^{\circ} \mathrm{C}$ for $72 \mathrm{~h}$, then filtered through a paper filter $\rightarrow$ tincture. Ethanol of 30, 40, 50, 60, 70, 80, 90 and 96\% concentrations was used as solvent.

Percolation procedure: dried rosemary leaves were moistened with $50 \%$ ethanol for $1.5 \mathrm{~h}$ and $4 \mathrm{~h}$ $(1: 10) \rightarrow$ all material was placed into the percolator and allowed to stand for 3 days $\rightarrow$ the first part ( $85 \%$ of final volume) of extract was percolated at a control rate (3 drops per minute) $\rightarrow$ the second part (15\% of final volume) of extract was percolated in the same rate with continuous addition of fresh solvent (till all needed volume for extraction was used) $\rightarrow$ the second part was concentrated by evaporation and filtered $\rightarrow$ the first and second parts were mixed and stored at $8{ }^{\circ} \mathrm{C}$ for $72 \mathrm{~h} \rightarrow$ filtration through a paper filter $\rightarrow$ extract.

\section{Total phenolic content}

Total phenolic content was measured by UV spectrophotometer UNICAM Helios a (Unicam, Cambridge, UK). Method is based on a colorimetric oxidation / reduction reaction using the Folin-Ciocalteau reagent with modifications (Singleton et al., 1965). As rosmarinic acid is one of the polyphenol compounds, the total phenolic content of extracts was expressed as rosemary acid equivalents. The standard calibration (0.0625$1.0 \mathrm{mg} / \mathrm{ml})$ curve was plotted $\left(\mathrm{R}^{2}=0.9989\right)$ using rosmarinic acid dissolved in distilled water. $1 \mathrm{ml}$ of the test solution, $5 \mathrm{ml}$ of Folin-Ciocalteu reagent (diluted 10 times with water) and $4 \mathrm{ml}$ of sodium carbonate $(75 \mathrm{~g} / \mathrm{L})$ were added. The sample was left for $30 \mathrm{~min}$ and the absorbance at $765 \mathrm{~nm}$ 
was measured. Results were expressed as milligrammes of rosmarinic acid equivalent per mililitre of ethanolic extract (RAE $\mathrm{mg} / \mathrm{ml}$ ).

\section{Antioxidant activity}

Antioxidant activity was determined by 2,2diphenyl-1-picrylhydrazyl (DPPH') free radical inactivation method. Ethanolic extracts of propolis $(50 \mu \mathrm{L})$ were mixed with $6 \times 10^{-5} \mathrm{M}$ methanolic $\mathrm{DPPH}^{\cdot}$ solution $(2.00 \mathrm{~mL})$ in $1 \mathrm{~cm}$ path length disposable cuvette (Bandoniene et al., 2002). The decrease in absorption at $515 \mathrm{~nm}$ was recorded after incubation period $20 \mathrm{~min}$ at room temperature. The absorbance was read on UNICAM Helios a UV spectrophotometer (Unicam, Cambridge, UK).

The percent inhibition of 2,2-diphenyl-1picrylhydrazyl $\left(\mathrm{DPPH}^{*}\right)$ free radical was calculated according to the formula:

$$
\mathrm{DPPH}_{(\% \text { inhibition })}=\left[\left(\mathrm{A}_{\text {blank }}-\mathrm{A}_{\text {sample }}\right) / \mathrm{A}_{\text {blank }} \times 100\right.
$$

where $A_{\text {blank }}$ is the absorbance of the blank solution and $\mathrm{A}_{\text {sample }}$ is the absorbance sample and 2,2diphenyl-1-picrylhydrazyl (DPPH$\left.{ }^{*}\right)$ free radical solution after $20 \mathrm{~min}$.

\section{Dry residue}

Dry residue was evaluated according to 2.8.16. European Pharmacopeia method: $2 \mathrm{ml}$ of extracts were dried in $100-105{ }^{\circ} \mathrm{C}$ temperature with moisture analyzer Kern MLS 50-3 (KERN \& Sohn GmbH, Germany).

\section{Statistical analysis}

Five independed determinations were performed at each concentration $(n=5)$. The data were pre- sented as means \pm standard deviation (SD). Statistical analysis was performed using Student's $t$-test, correlation matrixes test and $\mathrm{P}<0.05$ were used as the level of significance.

\section{RESULTS AND DISCUSSION}

Table 1 lists eight ethanol concentrations used for extraction and determined dry residue, total phenolic content and antioxidant activity of produced tinctures. The dry residue of tested tinctures ranged from $1.25 \%$ to $2.2 \%$. $50 \%$ ethanolic rosemary tincture had a statistically significant $(\mathrm{P}<0.0001)$ highest dry residue $2.2 \%$, therefore this concentration of solvent ethanol can be considered as most efficient.

Phenolic substances have been shown to be responsible for the antioxidant activity of plant materials (Kim et al., 2011). The highest amount of phenolics (49 $\mathrm{mg} / \mathrm{ml} \mathrm{RAE}$ ) was determined in the tincture produced with $50 \%$ ethanol, while $96 \%$ ethanol extracted the lowest value (19.5 $\mathrm{mg} / \mathrm{ml} \mathrm{RAE}$ ). The results of total phenolic content and dry residue do not correlate, but one similarity is that $50 \%$ ethanol showed the highest value compared with other concentrations of the used solvent.

Higher antioxidant activity has been positively correlated with the concentration of phenolic compounds in extracts (Bryngelsson et al., 2002; Sun et al., 2007). However, in this study, the free radical scavenging capability varied very slightly $72-85 \%$. There was no statistically significant difference $(\mathrm{P}>0.0624)$, the highest activity showed $90 \%$ ethanolic tincture of rosemary, whereas the lowest value was for 30\% ethanolic tincture. Similarly, no significant differences between the

Table 1 . The dry residue, total phenolic content and antioxidant activity of tinctures extracted with different ethanol concentrations

\begin{tabular}{c|c|c|c}
\hline $\begin{array}{c}\text { Solvent ethanol concentra- } \\
\text { tions used for extraction }\end{array}$ & $\begin{array}{c}\text { Dry residue, } \\
\%\end{array}$ & $\begin{array}{c}\text { Total phenolic content, } \\
\text { mg/ml RAE }\end{array}$ & $\begin{array}{c}\text { Antioxidant activity, } \\
\%\end{array}$ \\
\hline $30 \%$ & $1.25 \pm 0.05$ & $38 \pm 0.95$ & $72 \pm 2.05$ \\
\hline $40 \%$ & $1.5 \pm 0.06$ & $42 \pm 0.98$ & $80 \pm 3.05$ \\
\hline $50 \%$ & $2.2 \pm 0.06$ & $49 \pm 1.05$ & $80 \pm 3.15$ \\
\hline $60 \%$ & $1.6 \pm 0.05$ & $42.5 \pm 1.02$ & $82 \pm 3.25$ \\
\hline $70 \%$ & $1.7 \pm 0.06$ & $41 \pm 1.05$ & $81 \pm 3.15$ \\
\hline $80 \%$ & $1.75 \pm 0.07$ & $34.5 \pm 0.75$ & $80 \pm 3.15$ \\
\hline $90 \%$ & $1.55 \pm 0.05$ & $19.5 \pm 0.45$ & $85 \pm 3.55$ \\
\hline $96 \%$ & $1.7 \pm 0.06$ & $17.5 \pm 0.36$ & $78 \pm 2.15$ \\
\hline
\end{tabular}


DPPH inactivation was observed in the study of different methanolic extracts of rosemary callus (Ozlem et al., 2007). Correlation between the total phenolic content and antioxidant activity was not observed, too. In this study there was no correlation between antioxidant activity and phenolic content $\mathrm{r}=-0.15$; antioxidant activity and dry residue $r=0.36$. It may be due to different types of phenolic compounds being extracted with different concentrations of ethanol, but not the absolute amount. Antioxidant activity of substances may not be solely characterized by the total phenolic components and their particular structural characteristics (Shahidi et al., 1992).

Influence of solvent concentration on the quantity of rosemary tinctures was evaluated. The results showed that $50 \%$ ethanol extracts highest amount of phenolics, therefore it was used for rosemary extract production by a percolation method. Moistening time of raw material is not strictly regulated; therefore two time periods: $1.5 \mathrm{~h}$ and $4 \mathrm{~h}$ were applied in the experimental production. The results are listed in Table 2. There was no significant difference between the dry residue $(P=0.192)$, total phenolic content $(P=0.605)$ and antioxidant activity $(\mathrm{P}=0.917)$. Comparing results between rosemary tinctures and rosemary extracts, dry residue and amount of phenolics are higher in the extracts, although antioxidant activity is lower. 50\% ethanolic tincture showed $80 \%$ DPPH inactivation and 50\% ethanolic extract $-61 \%$.

As the results had shown still moistening did not demonstrate any dependence on applied time, therefore in further study stirring was employed using a magnetic stirrer (Yellowline TC 3, Imlab, Belgium). The dried rosemary leaves were moistened with $50 \%$ ethanol and from the next day periodical stirring started. Experimental maceration lasted 4 days, stirring rate -5 . The total amount of phenolic compounds was determined in the evaluation of stirring influence (Figure).

The total phenolic content without stirring increased on third day and remain on fourth day 65-66 mg/ml RAE. Stirring of rosemary leaves increased the total phenolics on the second already: from 42 till $53 \mathrm{mg} / \mathrm{ml}$ RAE. These results confirm that active moistening is effective and can increase the amount of extractive substances from herbal materials.

Table 2. The dry residue, total phenolic content and antioxidant activity of rosemary extract when different moistening time was applied in the production

\begin{tabular}{c|c|c|c}
\hline $\begin{array}{c}\text { Moistening time, } \\
\mathbf{h}\end{array}$ & $\begin{array}{c}\text { Dry residue, } \\
\%\end{array}$ & $\begin{array}{c}\text { Total phenolic content, } \\
\text { mg/ml RAE }\end{array}$ & $\begin{array}{c}\text { Antioxidant activity, } \\
\%\end{array}$ \\
\hline $1.5 \mathrm{~h}$ & $7.76 \pm 0.05$ & $212.5 \pm 0.05$ & $61.63 \pm 0.05$ \\
\hline $4 \mathrm{~h}$ & $7.21 \pm 0.05$ & $219.45 \pm 0.05$ & $61.58 \pm 0.05$ \\
\hline
\end{tabular}

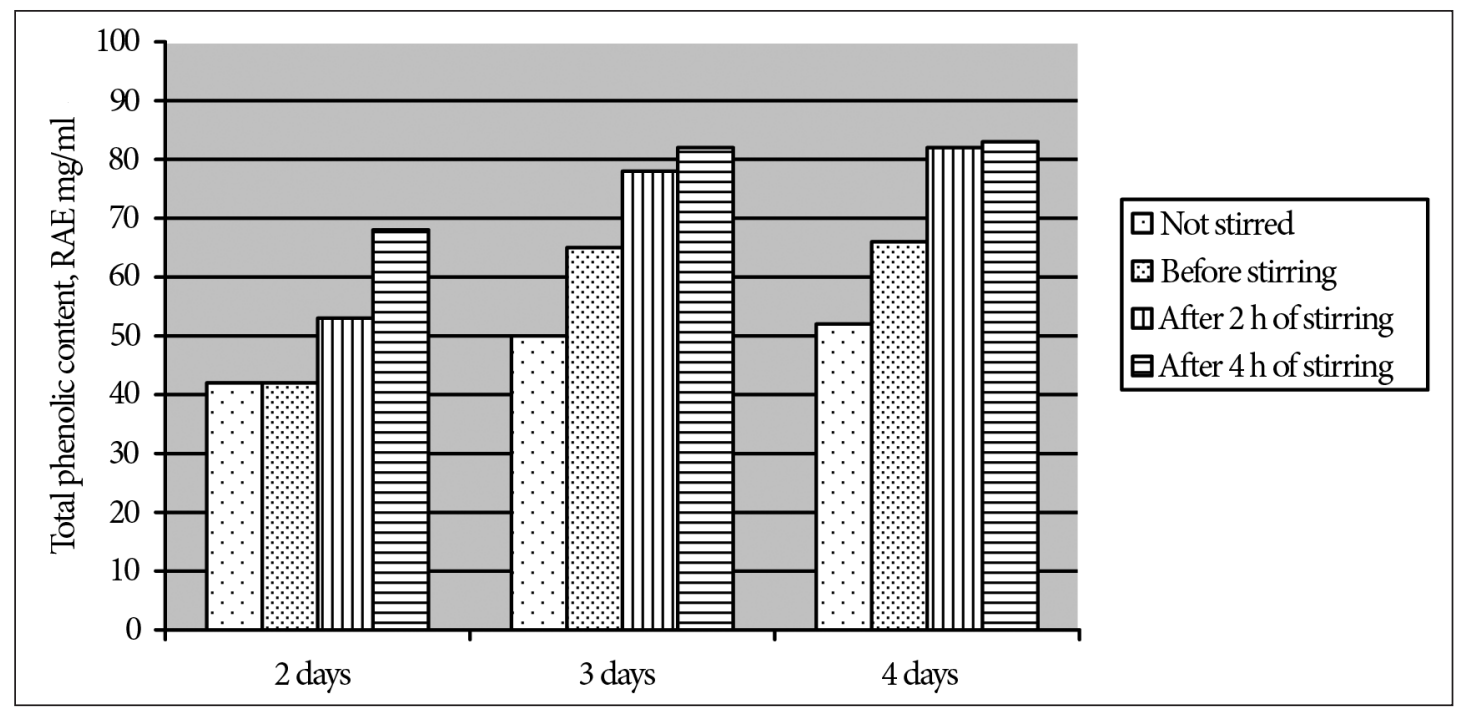

Figure. Total phenolic content of rosemary tinctures macerated with stirring 


\section{CONCLUSIONS}

The highest amount of phenolics $(49 \mathrm{mg} / \mathrm{ml}$ RAE) and dry residue (2.2\%) was determined in the tincture produced with $50 \%$ ethanol $(\mathrm{P}<0.0001)$, while antioxidant activity was high in all tested rosemary tinctures $(72-85 \%$ inactivation of DPPH). Extraction by percolation showed higher amounts of dry residue and phenolics, but antioxidant activity was lower. Correlation between the total phenolic content and antioxidant activity was not observed. Stirring of rosemary leaves increased the total phenolics (from 42 to $53 \mathrm{mg} / \mathrm{ml} \mathrm{RAE}$ ). These results confirm that active moistening is effective and can increase the amount of extractive substances from herbal materials.

Received 12 January 2013

Accepted 28 February 2013

\section{References}

1. Bandoniene D, Murkovic M, Pfannhauser W, Venskutonis PR, Gruzdiene D. Detection and activity evaluation of radical scavenging compounds by using DPPH free radical and on-line HPLC-DPPH methods. Eur Food Res Techn 2002; 214: 143-7.

2. Bryngelson S, Mannerstedt-Fogelfors B, KamalEldin A, Andersson R, Dimberg LH. Lipids and antioxidants in groats and hulls of Swedish oats (Avena sativa L.). J Sci Food Agric 2002; 82: 606-14.

3. Mulinaccia N, Innocentia M, Bellumoria M, Giaccherinia C, Martinib V, Michelozzib M. Storage method, drying processes and extraction procedures strongly affect the phenolic fraction of rosemary leaves: An HPLC/DAD/MS study. Talanta 2011; 85: 167-76.

4. Kalveniene Z, Savickas A, Svambaris LK, Briedis V, Bernatonis D. „Gaiviosios“ tinktūros technologijos kūrimas ir analizè [Development and analysis of technology of Revitalising tincture]. Medicina Kaunas 2002; 38(10): 1009-13 (in Lithuanian).

5. Kim IS, Yang MR, Lee OH, Kang SN. Antioxidant activities of hot water extracts from various spices. Int J Mol Sci 2011; 12: 4120-31.
6. Ozlem YC, Pinar N, Aynur G, Erdal B, Fazilet VS. Determination of phenolic content and antioxidant activity of extracts obtained from Rosmarinus officinalis' calli. J Plant Phys 2007; 164: 1536-42.

7. Ramanauskiene K, Savickas A, Bernatoniene J. Ekstrahavimo ịtaka skysto jonažolių ekstrakto kokybei [The influence of extraction method on the quality of the liquid extract of St. John's wort]. Medicina Kaunas 2004; 40: 745-749 (in Lithuanian).

8. Seifried HE, Anderson DE, Fisher EI, Milner JA. A review of the interaction among dietary antioxidants and reactive oxygen species. J Nutr Bioch 2007; 18: 567-79.

9. Shahidi F, Wanasundara PKJPD. Phenolic antioxidants. Crit Rev Food Sci Nutr 1992; 32: 67103.

10. Singleton VL, Rossi JR. Colorimetry of total phenolics with phosphomolybdic-phosphotungstic acid. Am J En Vitic 1965; 16: 144-58.

11. Sun T, Xu Z, Wu C-T, Janes M, Prinyawiwatkul W, No HK. Antioxidant activities of different colored sweet bell peppers (Capsicum annuum L.). J Food Sci 2007; 72: S98-102.

12. Valko M, Leibfritz D, Moncol J, Cronin MT, Mazur M, Telser J. Free radicals and antioxidants in normal physiological functions and human disease. Int J Bioch Cell Biol 2007; 39: 44-84.

Giedrė Kasparavičienė, Kristina Ramanauskienė, Arūnas Savickas, Saulè Velžienè, Zenona Kalvėnienė, Daiva Kazlauskienė, Ona Ragažinskienė, Kostas Ivanauskas

\section{BENDRO FENOLINIŲ JUNGINIŲ KIEKIO IR ANTIOKSIDACINIO AKTYVUMO IVERTINIMAS SKIRTINGOSE ROSMARINUS OFFICINALIS L. ETANOLINĖSE IŠTRAUKOSE}

\section{Santrauka}

Augaliniai ekstraktai yra vienas turtingiausių antioksidantų šaltinių, kurie neutralizuoja ir laisvuosius radikalus, ir reaktyvius deguonies junginius. Ekstrakcijai naudojami tirpikliai, taip pat ekstrakcijos sąlygos gali veikti kiekybę, antioksidantų sudètị ir biologinị aktyvumą. Etanolinès ištraukos iš rozmarino lapų buvo gaminamos maceracijos ir perkoliacijos būdais. Ekstrakcijai buvo naudotos 30, 40, 50, 60, 70, 80, 90 
ir $96 \%$ etanolio koncentracijos. Spektrofotometriškai buvo ivertintas etanolio koncentracijos ir ekstrahavimo metodo poveikis bendram fenolinių junginių kiekiui ir antioksidaciniam aktyvumui inaktyvuojant 1,1-difenil-2-pikrilhydrazyl (DPPH) radikalą.

Didžiausią fenolinių junginių kiekị - 47,39 $\pm 0,21$ $\mathrm{mg} / \mathrm{mL} \mathrm{RRE}$ - ekstrahavo $50 \%$ etanolis perkoliacijos metodu. Visos tirtos etanolinès rozmarino ištraukos pasižymejo aukštu antioksidaciniu aktyvumu, kuris svyravo nuo 75,96 $\pm 1,12 \%$ iki $85,81 \pm 0,14 \%$, bet statistiškai patikimo skirtumo nenustatyta $(\mathrm{P}>0,0624)$. Taip pat nustatyta, kad sausasis likutis buvo didesnis tirtų skystụjų ekstraktų nei tinktūrų. Rozmarino lapų maišymas brinkinimo metu padidino bendrą fenolinių junginių (nuo 42 iki $53 \mathrm{mg} / \mathrm{ml} \mathrm{RRE)} \mathrm{kieki} 50$ \% etanolinëje rozmarino tinktūroje. Ekstrahavimas perkoliacijos būdu padidino sausojo likučio ir fenolinių junginių kiekius, bet sumažino antioksidacinị aktyvumą. Koreliacija tarp bendro fenolinių junginių kiekio ir antioksidacinio aktyvumo nebuvo nustatyta. Aktyvus brinkinimas yra efektyvus ir gali padidinti veikliųjų medžiagų išekstrahavimą iš augalinių žaliavų.

Raktažodžiai: Rosmarinus officinalis L., fenoliniai junginiai, antioksidacinis aktyvumas, etanolinès ištraukos 